\title{
Etiologies and Outcome of Children with Purulent Meningitis at the Yaounde Gyneco-Obstetric and Pediatric Hospital (Cameroon)
}

\author{
Séraphin Nguefack ${ }^{1,2}$, Andréas Chiabi1,2, Jacob Enoh ${ }^{1,3}$, El Hadji Djouberou ${ }^{2}$, Evelyn Mah ${ }^{1,2}$, \\ Karen Kengne Kamga ${ }^{1}$, Sandra Tatah ${ }^{2}$, Elie Mbonda ${ }^{1,2}$ \\ ${ }^{1}$ Departement of Pediatric Neurology, Yaounde Gynaeco-Obstetric and Pediatric Hospital, Yaounde, Cameroon \\ ${ }^{2}$ Faculty of Medicine and Biomedical Sciences, University of Yaounde I, Yaounde, Cameroon \\ ${ }^{3}$ Departement of Pediatric, University of Cocody-Abidjan, Abidjan, Côte d'Ivoire \\ Email: seraphin nguefack@yahoo.fr
}

Received 14 September 2014; revised 8 October 2014; accepted 5 November 2014

Academic Editor: Carl E. Hunt, George Washington University School of Medicine and Health Sciences, USA

Copyright (C) 2014 by authors and Scientific Research Publishing Inc.

This work is licensed under the Creative Commons Attribution International License (CC BY).

http://creativecommons.org/licenses/by/4.0/

(c) (i) Open Access

\section{Abstract}

Background: Bacterial meningitis is one of the most severe infections in infants and children. It is associated with high mortality and neurological sequelae. In order to improve the prognosis of infants and children with purulent meningitis, we decided to conduct this study whose main objective was to identify the main pathogens responsible and describe the outcome in infants and children aged 2 months to 15 years admitted for purulent meningitis at the Yaounde Gyneco-Obstetric and Pediatric Hospital (YGOPH). Method: This was a cross-sectional study with retrospective data collection and consecutive sampling. Our study was conducted from 1 January 2009 to 31 December 2013. The patients included in the study were infants and children aged from 2 months to 15 years who were admitted for bacterial meningitis at the YGOPH, confirmed by bacteriological examination of cerebrospinal fluid (CSF) with identification of the pathogen by culture or soluble antigen. The data was analyzed using SPSS Version 18.0 and Excel 2007. The Chi-square test was used to determine the association of various variables. The significance threshold was set as $P<$ 0.05. Results: We selected 171 cases of purulent meningitis who represented $1.54 \%$ of admitted patients. The sex ratio was 1.2 . We noted that $45 \%$ of our patients were aged 2 months to 1 year. The main presenting complaints were fever (98.8\%), seizures $(44.4 \%)$ and vomiting $(28.7 \%)$. Haemophilus influenzae was found in 67 children (39.2\%), followed by Streptococcus pneumoniae

\footnotetext{
*Corresponding author.
}

How to cite this paper: Nguefack, S., Chiabi, A., Enoh, J., Djouberou, E.H., Mah, E., Kamga, K.K., Tatah, S. and Mbonda, E. (2014) Etiologies and Outcome of Children with Purulent Meningitis at the Yaounde Gyneco-Obstetric and Pediatric Hospital (Cameroon). Open Journal of Pediatrics, 4, 269-275. http://dx.doi.org/10.4236/ojped.2014.44037 
in 54 children (31.6\%) and Neisseria meningitidis in 17 children $(9.9 \%)$. Acute complications (status epilepticus, coma) were seen in $33 \%$ of patients. The statistically significant $(P<0.05)$ factors for poor prognosis were aged from 2 months to 1 year $(P=0.0004)$, coma $(P=0.32)$, intracranial hypertension $(P=0.0001)$, the pathogen $(P=0.0032$ Pneumococcus $)$, a delay of more than three days between the onset of the disease and the treatment $(P=0.0134)$ and brain abscess $(P=$ $0.0001)$. We identified 32 deaths $(18.7 \%)$ and 17 cases $(9.9 \%)$ with neurological sequelae before discharge. Conclusion: The incidence of acute bacterial meningitis remains high in our context. The main causes were Haemophilus influenzae, Streptococcus pneumoniae and Neisseria meningitis. The mortality rate was high with poor prognosis factors such as age less than $\mathbf{1 2}$ months, delayed care, pneumococcal meningitis, coma, brain abscess, and intracranial hypertension. Focus should be placed on strengthening the routine immunization on vaccine-preventable diseases of infants and children against Haemophilus influenzae, Pneumococcus and Meningococcus.

\section{Keywords}

\section{Bacterial Meningitis, Etiologies, Outcome, Children, Cameroon}

\section{Introduction}

Meningitis is one of the most severe infections in infants and children with an incidence of 25 per 100,000 children in Africa [1]. This infection is associated with high rates of acute complications, death and the risk of long-term morbidity. Its outcome was generally fatal before the advent of antibiotics whose discovery, along with those of vaccines, improved on the incidence and prognosis of the disease [2] [3].

Although morbidity, mortality and occurrence of sequelae have diminished, these continue to be important in the pediatric population of developing countries, and their severity is highest in infants and children [3]. In 2012, in the course of the surveillance of meningitis in Africa the World Health Organization (WHO) [4] identified 22,000 meningitis cases in 14 countries in the meningitis belt. In Cameroon, several studies have been done on this subject [5]-[8]. Case fatality rates ranging from $8 \%$ to $27.44 \%$ and rates of appearance of sequelae ranging from $4 \%-20 \%$ have been reported in studies conducted in different parts of the country [5]-[8]. In order to improve the prognosis of bacterial meningitis in infants and children in our environment, we decided to conduct this study whose aim was to determine the etiology and describe the prognosis in infants and children aged 2 months to 15 years who had been admitted for purulent meningitis at the Yaounde Gyneco-obstetric and Pediatric Hospital.

\section{Method}

This was a descriptive cross-sectional study, with retrospective data collection for the period from 1 January 2009 to 31 December 2013. Sampling was consecutive. All patients aged 2 months to 15 years admitted in the pediatric unit with the diagnosis of bacterial meningitis based on the clinical and bacteriological criteria, through identification of the pathogen in CSF culture or soluble antigen in the CSF. We excluded patients in whom the diagnosis of meningitis was established but the pathogen was not identified. We selected all patients with meningitis who fulfilled our inclusion criteria through the registers of the pediatric unit. Data collected included: gender, age, weight of the child, the clinical signs of the child at the time of admission, the findings of the physical examination, the results of the cytology and bacteriology CSF analysis, CSF soluble antigen test, acute complications (death, altered state of consciousness, status epilepticus), sequelae at the time of discharge (psychomotor regression, motor deficit, hydrocephalus). The results were analyzed using SPSS 18.0 and Microsoft Office Excel 2007. The statistical test Chi-square was used to determine associations between variables. The significance threshold was set as $\mathrm{P}<0.05$.

\section{Results}

\subsection{Study Population}

We included 171 patients aged 2 months to 15 years seen between 1 January 2009 and 31 December 2013, with 
purulent meningitis, in whom a pathogen had been identified. During the same period we had 11035 patients aged 2 months to 15 years admitted in the unit, thus patients with purulent meningitis represented $1.54 \%$ of admitted patients. We noted a peak incidence in the age group of 2 to 12 -month (45\%, Figure 1$)$. The average age was $39.4 \pm 32.1$ months and age range 2 months to 15 years. The sex ratio was 1.2.

\subsection{Presenting Complaints}

The main presenting complaints were fever (98.8\%), seizures (44.4\%) and vomiting (28.7\%) (Table 1).

\subsection{Etiologies}

Haemophilus influenzae was the most common pathogen (Table 2). It constituted 39.2\% of organisms that caused purulent meningitis, followed by Streptococcus pneumoniae with $31.6 \%$ of the cases. In the age group from 2 months to 2 years Haemophilus influenzae was most incriminated.

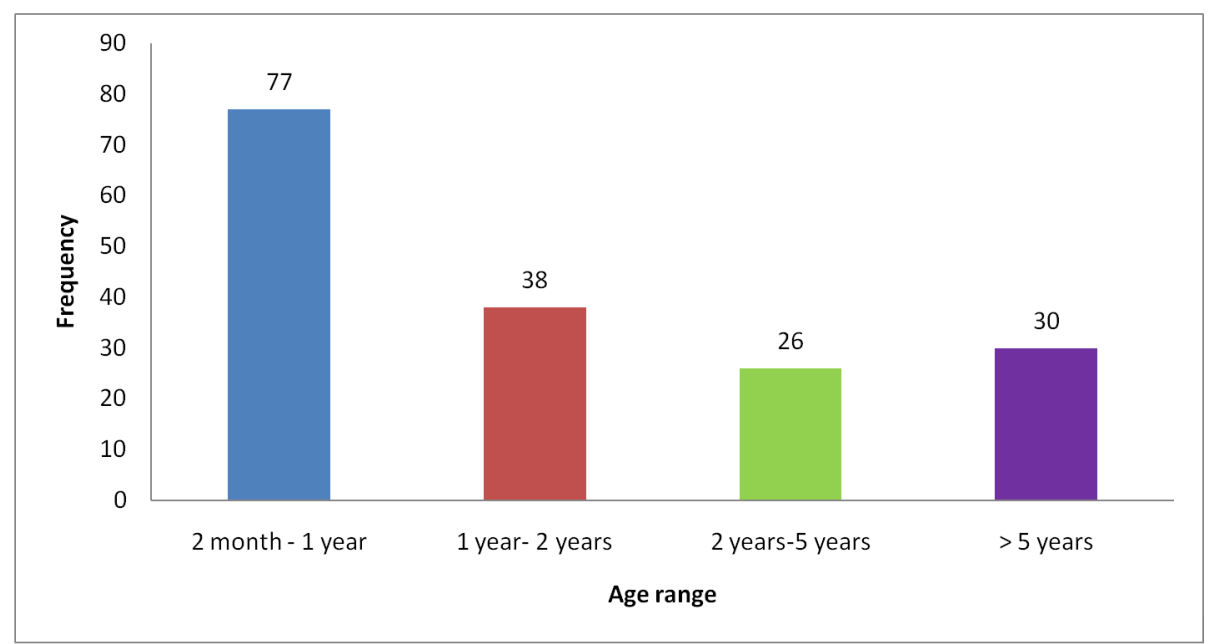

Figure 1. Distribution of patients according to age groups.

Table 1. Distribution of patients according to the chief complaint.

\begin{tabular}{|c|c|c|}
\hline Symptoms & Number & Percentage (\%) \\
\hline Fever & 169 & (98.8) \\
\hline Seizures & 76 & $(44.4)$ \\
\hline Vomiting & 49 & (28.7) \\
\hline Coma & 30 & $(17.5)$ \\
\hline Irritability & 28 & (16.4) \\
\hline Head ache & 20 & (11.7) \\
\hline Agitation & 19 & (11.1) \\
\hline Grunting & 8 & $(4.7)$ \\
\hline Excessive crying & 7 & $(4.1)$ \\
\hline Somnolence & 6 & (3.5) \\
\hline Constipation & 4 & $(2.3)$ \\
\hline Photophobia & 2 & $(1.2)$ \\
\hline Refuse to breast feed & 2 & $(1.2)$ \\
\hline Purpura fulminans & 2 & $(1.2)$ \\
\hline
\end{tabular}


Table 2. Distribution of pathogens according to age.

\begin{tabular}{|c|c|c|c|c|c|}
\hline Germs & 2 month - 1 yr & $1 \mathrm{yr}-2 \mathrm{yr}$ & $2 y r-5 y r$ & $>5 \mathrm{yr}$ & Total \\
\hline H.influenzae & 43 & 13 & 2 & 9 & 67 \\
\hline S. pneumoniae & 19 & 9 & 15 & 11 & 54 \\
\hline N. meningitidis & 2 & 3 & 8 & 5 & 18 \\
\hline Group B Streptococcus & 6 & 5 & 0 & 0 & 11 \\
\hline Group C Streptococcus & 1 & 0 & 0 & 5 & 6 \\
\hline Salmonella & 2 & 2 & 0 & 0 & 4 \\
\hline E. coli & 0 & 2 & 0 & 0 & 2 \\
\hline Klebsiella pneumoniae & 2 & 0 & 0 & 0 & 2 \\
\hline Pasteurella sp & 1 & 1 & 0 & 0 & 2 \\
\hline Staphylococcus aureus & 0 & 2 & 0 & 0 & 2 \\
\hline Citrobacter sp & 0 & 1 & 0 & 0 & 1 \\
\hline Pseudomonas aeruginosa & 0 & 0 & 1 & 0 & 1 \\
\hline Other streptococcus sp & 1 & 0 & 0 & 0 & 1 \\
\hline Total & 77 & 38 & 26 & 30 & 171 \\
\hline
\end{tabular}

\subsection{Outcome and Sequelae}

The average number of days of hospitalization was 15.35 days \pm 8.851 days, ranging from 1 day to 41 days. The period of time between onset of fever and that of antibiotics ranged from 1 to 23 days giving an average of 4.8 days \pm 4 days. Fifty-seven patients (33.3\%) had complications during hospitalization (Table 3). Note that the same patient may have had several complications simultaneously. Status epilepticus and coma were the main complications during hospitalization (Table 3). The mortality rate observed in our study was $18.7 \%$ (32 deaths); 122 patients $(71.3 \%)$ recovered without immediate sequelae and $9.9 \%$ had recovered with immediate sequelae (Table 4). We found a statistically significant association $(\mathrm{P}<0.05)$ between alteration of consciousness, intracranial hypertension, cerebral abscess and progression to neurological sequelae and death. We equally found a statistically significant association $(\mathrm{P}<0.05$ ) between Streptococcus pneumoniae, Haemophilus influenzae and poor clinical outcome. We recorded 17 deaths (53.1\%), and $44.4 \%$ of the sequelae were due pneumococcal infection, thus making it the most virulent pathogen. Other poor prognostic factors $(\mathrm{P}<0.05)$ were age less than 12 months and the delayed care above 3 days after onset of symptoms.

\section{Discussion}

The incidence of bacterial meningitis in our study remained high with $1.54 \%$ of admissions. This figure could be underestimated because we excluded patients in whom the pathogen was not identified. The sex ratio of 1.2 was close to Faye [9] in Ivory Coast who found a sex ratio of 1.3 in 2003. Meanwhile Sile [6] in northern Cameroon found a sex ratio of 1.6 in 1999. We did not find an explanation for this male predominance. The average age of our patients was 32.1 months with a standard deviation of 39.4, close to the average age of most authors [5] [10] [11]. Clinically, the study noted that the major symptoms to suggest meningitis in infants and children were fever, seizures and vomiting in respectively $98.8 \%, 44.4 \%$ and $28.7 \%$ of patients (Table 1 ).

In our study, Haemophilus influenzae was the most common pathogen, found in $39.2 \%$ of the patients, followed by Streptococcus pneumoniae and Neisseria meningitidis with respectively 31.6 and $10.5 \%$ of the patients (Table 2). In a study done in the same unit between 2004 and 2009 Haemophilus influenzae was the most commonly identified pathogen followed by Streptococcus pneumoniae and Neisseria meningitidis, respectively, in 40.3\%, 34.2\% and 5.4\% [5]. Our results are also similar to those reported in Senegal by Cisse [12] who found Haemophilus influenzae (42.3\%) followed by Streptococcus pneumoniae (31.9\%) and Neisseria meningitidis (11.2\%). Almuneef [13] in Saudi Arabia also identified Haemophilus influenzae as the first pathogen in bacterial meningitis in persons younger than 5 years followed by pneumococcus and meningococcus. Other authors [14] [15] in Mozambique and Angola also had, with some variation at the relative frequencies, globally the same results as our study with Haemophilus influenzae as the first cause of meningitis before the age of 15 years. How- 
Table 3. Complications found during hospitalization.

\begin{tabular}{ccc}
\hline Complications & Number & Percentage (\%) \\
\hline Status epilepticus & 40 & 54.7 \\
Coma & 18 & 24.6 \\
Motor deficits & 9 & 12.3 \\
Cerebral abscess & 4 & 5.4 \\
ICHT $^{*}$ & 1 & 1.3 \\
Digestive haemorrhage & 1 & 1.3 \\
Total & 73 & 100 \\
\hline
\end{tabular}

*Intracranial hypertension.

Table 4. Distribution of patients according to sequelae at time of hospital discharge.

\begin{tabular}{ccc}
\hline Sequelae & Number & Percentage (\%) \\
\hline Psychomotor Regression & 5 & 2.9 \\
Deafness & 4 & 2.4 \\
Hemiparesis & 4 & 2.4 \\
Hydrocephaly & 3 & 1.8 \\
Tetra paresis & 2 & 1.2 \\
Facial paralysis & 1 & 0.6 \\
Total & 17 & 9.9 \\
\hline
\end{tabular}

ever other studies [7] [8] [16] done locally in Cameroon and other African studies [1] [17] [18] reported, with some variation in the relative frequencies, a predominance of Streptococcus pneumoniae, followed by Haemophilus influenzae and Neisseria meningitis. Massenet [19] in a study in the northern part of Cameroon found a high prevalence of Neisseria meningitidis with $70.2 \%$, followed by $19.5 \%$ with Streptococcus pneumoniae and Haemophilus influenzae with $10.3 \%$. This predominance of Neisseria meningitidis in the study of Massenet is explained by the fact that the study was conducted in the northern part of the country which lies in the African meningitis belt. The predominance of Haemophilus in our study may be related to selection bias because we have included only the patients who had a positive culture or positive soluble antigen. However the high incidence of meningitis caused by Haemophilus influenzae may also be related to the lack of vaccination in most of these patients, because since the vaccine was introduced in 2008, a decrease in the incidence of Haemophilus influenzae meningitis was expected. This is unlike the study of Wall [17] in Malawi that showed a significant decline in Haemophilus influenzae meningitis after the introduction of the vaccine.

The mortality rate observed in our study was $18.5 \%$. This rate is close to the mortality rate of $21.8 \%$ presented by Gervaix [8] in Cameroon in 2012 and the 20.3\% of deaths found by Gomes [20]. It is less than the mortality rate reported in other studies [7] [10] in Cameroon which were respectively 27.4\% and 29.8\%. This mortality rate is also lower than the 24\% found by Roca [14] in Mozambique. The most vulnerable age group is that of two months to one year, which represented $43.7 \%$ of deaths and $38.8 \%$ of sequelae. The vulnerability of children under one year was also found by other authors [7] [8].

Streptococcus pneumoniae was the pathogen responsible for most of the deaths and sequelae in our study as confirmed by several other studies [7] [8] [21]-[23]. Seventeen patients had at least one sequela at the time of discharge representing of 9.9\%. This rate is similar to that found by Moufdi [24] who reported 10.2\% of sequelae at time of discharge. This frequency of sequelae is probably underestimated because of the absence of an evaluation long after the acute episode. In evaluating these patients later, these sequelae would certainly be more severe.

The poor prognostic factors were age $<12$ months, pneumococcal infection, delayed care $>3$ days, the presence of a coma, and signs of intracranial hypertension. Pelkonen [15] in Angola found as poor prognostic fac- 
tors coma and delayed care, while Gervaix [8] found as poor prognostic factors: age < 2 years and pneumococcal infection. Farag [25] found age $<12$ months, and Kirimi [26] in Turkey had coma as a factor of poor prognosis.

\section{Conclusion}

The incidence of acute bacterial meningitis remains high in our context. The main causative pathogens are Haemophilus influenzae, Streptococcus pneumoniae and Neisseria meningitidis. The mortality and acute sequelae remain high with poor prognostic factors such as age less than 12 months, delays in care, pneumococcal meningitis, coma, brain abscess, and intracranial hypertension. A focus should be placed on strengthening the routine immunization on vaccine-preventable diseases of infants and children against Haemophilus influenzae, pneumococcus and meningococcus.

\section{References}

[1] Peltola, H. (2001) Burden of Meningitis and Order Severe Infection of Children in Africa: Implications for Prevention. Clinical Infetious Diseases, 31, 64-75. http://dx.doi.org/10.1086/317534

[2] Chavez-Bueno, S. and McCracken, G.H. (2005) Bacterial Meningitis in Children. Pediatric Clinics of North America, 52, 795-810. http://dx.doi.org/10.1016/j.pcl.2005.02.011

[3] Koko, J., Dufillot, D. and Gahouma, D. (1996) Mortalité hospitalière dans le service de pédiatrie générale de L’Hôpital pédiatrique d’Owando (Libreville-Gabon): Aspects caractéristiques. Annales de Pédiatrie, 43, 624-630.

[4] Organisation Mondiale de la santé (2012) Rapport sur les statistiques de santé dans le monde disponible sur le site. http://who.int/gho/publication/world-health-statistics/full.pdf

[5] Tiodoung, T.A. (2008) Aspects cliniques, bactériologiques, thérapeutiques et évolutifs des méningites bactériennes du nourrisson et de l'enfant à propos de 149 cas à l'HGOPY. Université des Montagnes, Cameroon.

[6] Sile, M.H., Sile, H., Mbonda, E., Feuzeu, R. and Fonkoua, M.C. (1999) Les méningites purulentes de l'enfant au Nord Cameroun: aspects cliniques, bactériologiques et thérapeutiques. Médecine d'Afrique Noire, 46, 16-20.

[7] Bernard-Bonin, A.C. and Tetanye, E. (1985) Les méningites purulentes de l’enfant à Yaoundé: Aspects épidémiologiques et pronostiques. Annales de la Société Belge de Médecine Tropicale, 65, 59-68.

[8] Gervaix, A., Taguebue, J., Bescher, B.N., et al. (2012) Bacterial Meningitis and Pneumococcal Serotype Distribution in Children in Cameroon. The Pediatric Infectious Diseases Journal, 31, 1084-1087.

[9] Faye, K., Doukou, E.S., Boni, C., Akoua-Koffi, C. and Diallo-Touré, K. (2003) Agents des méningites purulentes communautaires de l'enfant: Tendance épidémiologique à Abidjan, Cote d'Ivoire, de 1999 à l'an 2000. Bulletin de la Société de Patholologie Exotique, 96, 313-316.

[10] Ntapli, A. (1993) Etude des séquelles neurologiques des méningites bactériennes chez le nourrisson et l'enfant à l’hôpital central de Yaoundé. Thèse de Médecine. Université de Yaoundé I.

[11] Bingen, E.C., Lévy, F., De la Rocque, M., Boucherat, Y. and Aujard, R.C. (2005) Méningites à pneumocoque de l'enfant en France : Age de survenue et facteurs de risque médicaux. Archives de Pédiatrie, 12, 1187-1189. http://dx.doi.org/10.1016/j.arcped.2005.04.076

[12] Cisse, E., Sow, H.D., Ouangre, A.R., Gaye, A., Sow, A.I., Samb, A. and Fall, M. (1989) Méningites bactériennes dans un hôpital pédiatrique en zone tropicale. Médecine Tropicale, 49, 265-269.

[13] Almuneef, M., Memish, Z., Khan, Y., Kagallwala, A. and Alshaalan, M. (1998) Childhood Bacterial Meningitis in Saudia Arabia. Journal of Infection, 36,157-160. http://dx.doi.org/10.1016/S0163-4453(98)80005-4

[14] Roca, A., Bassat, Q., Morais, L., Machevo, S., Sigaúque, B., O’Callaghan, C., et al. (2009) Surveillance of Acute Bacterial Meningitis among Children Admitted to a District Hospital in Rural Mozambique. Clinical Infectious Diseases, 48, S172-S180. http://dx.doi.org/10.1086/596497

[15] Pelkonen, T., Roine, I., Monteiro, L., Correia, M., Pitkäranta, A., Bernardino, L. and Peltola, H. (2009) Risks Factors for Death and Severe Neurological Sequelae in Childhood Bacterial Meningitis in Sub-Saharan Africa. Clinical Infectious Diseases, 48, 1107-1110. http://dx.doi.org/10.1086/597463

[16] Fonkoua, M.C., Cunin, P., Sorlin, P., Musi, J. and Martin, M.V. (2001) Les méningites d'étiologie bactérienne à Yaoundé (Cameroun) en 1999-2000. Bulletin de la Société de Pathologie Exotique, 94, 300-303.

[17] Wall, E.C., Everett, D.B., Mukaka, M., Bar-Zeev, N., Feasey, N., Jahn, A., et al. (2014) Bacterial Meningitis in Malawian Adults, Adolescents, and Children during the Era of Antiretroviral Scale-Up and Haemophilus influenza Type b Vaccination, 2000-2012. Clinical Infectious Diseases, 58, 137-145. http://dx.doi.org/10.1093/cid/ciu057 
[18] Kisakye, A., Mukambi, I., Nansera, D., Lewis, R., Braka, F., Wobudeya, E., et al. (2009) Surveillance for Streptoccus pneumoniae Méningitis in Children Aged < 5 Years: Implication for Immunization in Uganda. Clinical Infectious Diseases, 48, S153-S161. http://dx.doi.org/10.1086/596495

[19] Massenet, D., Birguel, J., Azowe, F., Ebong, C., Gake, B., Lombart, J.-P. and Boisier, P. (2013) Epidemiologic Pattern of Meningococcal Meningitis in Northern Cameroon in 2007-2010: Contribution of PCR-Enhanced Surveillance. Pathogens and Global Health, 107, 15-20. http://dx.doi.org/10.1179/2047773212Y.0000000070

[20] Gomes, I., Melo, A., Lucena, R., Cunha-Nascimento, M.H., Ferreira, A., Góes, J., et al. (1996) Prognosis of Bacterial Meningitis in Children. Arquivos de Neuro-Psiquiatria, 53, 407-411. http://dx.doi.org/10.1590/S0004-282X1996000300008

[21] Yaro, S., Lourd, M., Traore, Y., Njanpop-Lafourcade, B.-M., Sawadogo, A., Sangare, L., et al. (2006) Epidemiological and Molecular Characteristics of Highly Lethal Pneuococcal Meningitis Epidemic in Burkina Faso. Clinical Infectious Diseases, 43, 693-700. http://dx.doi.org/10.1086/506940

[22] Tetanye, E., Yondo, D., Bernard-Bonnin, A.C., Tchokoteu, P.F., Kago, I., Ndayo, M. and Mbede, J. (1990) Initial Treatment of Bacterial Meningitis in Yaounde, Cameroon: Theoretical Benefits of Ampicilline-Chloramphenicol Combination versus Chloramphenicol Alone. Annals of Tropical Paediatrics, 10, 285-291.

[23] Thabet, F., Tilouche, S., Tabarki, B., Amrib, F., Guedichec, M.-N., Sfar, M.-T., et al. (2007) Mortalité par méningites à pneumocoque chez l'enfant. Facteurs pronostiques à propos d'une série de 73 observations. Archives de Pédiatrie, 14, 334-337. http://dx.doi.org/10.1016/j.arcped.2006.11.012

[24] Moufdi, A. (2007) Les méningites purulentes du nourrisson et de l’enfant. Thèse de Médecine, Université Mohamed V-Souissi de Rabat, Rabat.

[25] Farag, H.F., Abdel-Fattah, M.M. and Youssri, A.M. (2005) Epidemiological, Clinical and Prognostic Profile of Acute Bacterial Meningitis among Children in Alexandria, Egypt. Indian Journal of Medical Microbiology, 23, 95-101. http://dx.doi.org/10.4103/0255-0857.16047

[26] Kirimi, E., Tuncer, O., Arslan, S., Ataş, B., Caksen, H., Uner, A. and Oner, A.F. (2003) Prognostic Factors in Children with Purulent Meningitis in Turkey. Acta Medica Okayama, 57, 39-44. 
Scientific Research Publishing (SCIRP) is one of the largest Open Access journal publishers. It is currently publishing more than 200 open access, online, peer-reviewed journals covering a wide range of academic disciplines. SCIRP serves the worldwide academic communities and contributes to the progress and application of science with its publication.

Other selected journals from SCIRP are listed as below. Submit your manuscript to us via either submit@scirp.org or Online Submission Portal.
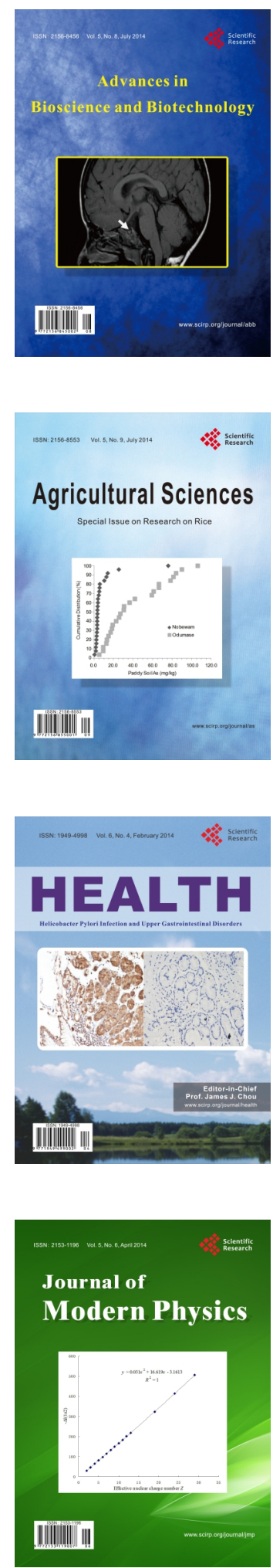
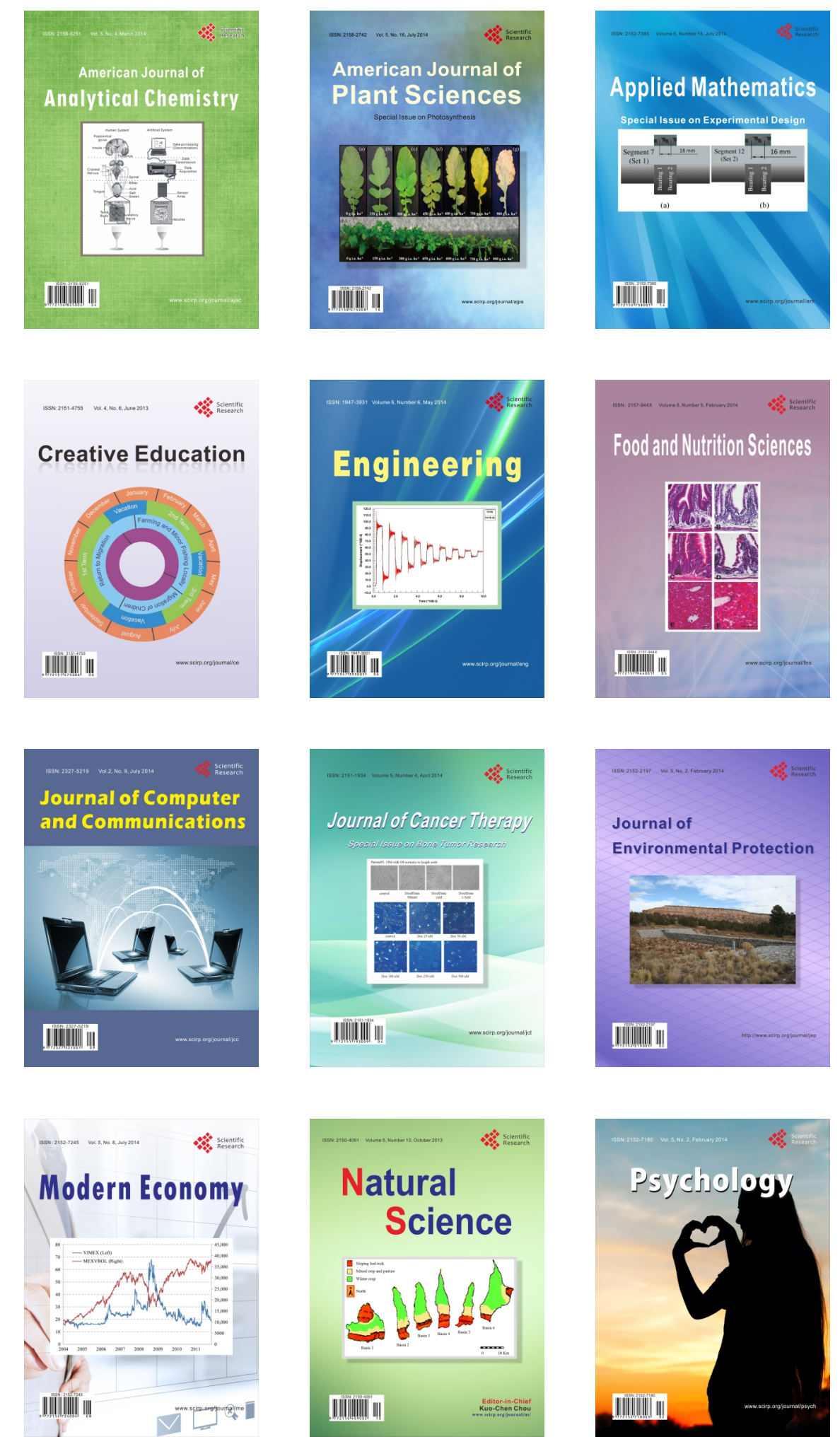